\title{
BMJ Global Health Lockdown measures in response to COVID-19 in nine sub-Saharan African countries
}

\author{
Najmul Haider (D) , ${ }^{1}$ Abdinasir Yusuf Osman, ${ }^{1}$ Audrey Gadzekpo, ${ }^{2}$ \\ George O Akipede, ${ }^{3}$ Danny Asogun, ${ }^{4}$ Rashid Ansumana, ${ }^{5}$ Richard John Lessells, ${ }^{6}$ \\ Palwasha Khan, ${ }^{7}$ Muzamil Mahdi Abdel Hamid (D), ${ }^{8}$ Dorothy Yeboah-Manu, ${ }^{9}$ \\ Leonard Mboera (D) , ${ }^{10}$ Elizabeth Henry Shayo, ${ }^{11}$ Blandina T Mmbaga, ${ }^{12,13}$ \\ Mark Urassa, ${ }^{14}$ David Musoke (D) , ${ }^{15}$ Nathan Kapata, ${ }^{16}$ Rashida Abbas Ferrand, ${ }^{17,18}$ \\ Pascalina-Chanda Kapata, ${ }^{16}$ Florian Stigler, ${ }^{19}$ Thomas Czypionka, ${ }^{20,21}$ \\ Alimuddin Zumla, ${ }^{22}$ Richard Kock, ${ }^{1}$ David McCoy ${ }^{23}$
}

To cite: Haider $\mathrm{N}$ Osman AY, Gadzekpo A, et al. Lockdown measures in response to COVID-19 in nine sub-Saharan African countries. BMJ Global Health 2020;5:e003319. doi:10.1136/ bmjgh-2020-003319

Handling editor Seye Abimbola

Received 1 July 2020

Revised 9 September 2020

Accepted 11 September 2020

Check for updates

C Author(s) (or their employer(s)) 2020. Re-use permitted under CC BY-NC. No commercial re-use. See rights and permissions. Published by BMJ.

For numbered affiliations see end of article.

Correspondence to Dr David McCoy;

d.mccoy@qmul.ac.uk

\section{ABSTRACT}

Lockdown measures have been introduced worldwide to contain the transmission of COVID-19. However, the term 'lockdown' is not well-defined. Indeed, WHO's reference to 'so-called lockdown measures' indicates the absence of a clear and universally accepted definition of the term 'lockdown'. We propose a definition of 'lockdown' based on a two-by-two matrix that categorises different communicable disease measures based on whether they are compulsory or voluntary; and whether they are targeted at identifiable individuals or facilities, or whether they are applied indiscriminately to a general population or area. Using this definition, we describe the design, timing and implementation of lockdown measures in nine countries in sub-Saharan Africa: Ghana, Nigeria, South Africa, Sierra Leone, Sudan, Tanzania, Uganda, Zambia and Zimbabwe. While there were some commonalities in the implementation of lockdown across these countries, a more notable finding was the variation in the design, timing and implementation of lockdown measures. We also found that the number of reported cases is heavily dependent on the number of tests carried out, and that testing rates ranged from 2031 to 63928 per million population up until 7 September 2020. The reported number of COVID-19 deaths per million population also varies ( 0.4 to 250 up until 7 September 2020), but is generally low when compared with countries in Europe and North America. While lockdown measures may have helped inhibit community transmission, the pattern and nature of the epidemic remains unclear. However, there are signs of lockdown harming health by affecting the functioning of the health system and causing social and economic disruption.

\section{INTRODUCTION}

Thus far, COVID-19 caused by SARS-CoV-2 which was officially declared as pandemic by WHO in March 2020 appears to have mainly affected wealthier countries. As of 7
Summary box

Lockdown measures have been introduced worldwide to contain the transmission of COVID-19.

- A number of studies showed positive impacts of lockdown in China and European countries.

- Although the term 'lockdown' is now ubiquitous, it is not well-defined.

- There are also no clear definitions of commonly used adjectives for the term such as 'total lockdown' and 'partial lockdown'; and 'hard' or a 'soft' lockdown.

- We have define 'lockdown' using a two-by-two matrix based on whether measures are compulsory or voluntary; and whether they are targeted at identifiable individuals and facilities, or applied indiscriminately to a general population.

- We describe the design, timing and implementation of lockdown in nine countries in sub-Saharan Africa: Ghana, Nigeria, South Africa, Sierra Leone, Sudan, Tanzania, Uganda, Zambia and Zimbabwe.

- This paper highlights the need for intersectoral and transdisciplinary research capable of providing a rigorous and holistic assessment of the harms and benefits of lockdown.

September 2020, 66\% of all reported cases globally were from countries in Europe and American continents. ${ }^{1}$ Although it was predicted that Africa's epidemic would be delayed compared with Europe and North America due to the relatively lower risk of cases being imported from China, ${ }^{2}{ }^{3}$ the number and proportion of reported cases in Africa remains low, amounting to only 1312592 cases or $5 \%$ of the global total at that time (with South Africa, Egypt, Nigeria and Ghana recording the most cases). ${ }^{1}$

The reported data from Africa are likely to underestimate the true magnitude of the 
pandemic due to underdetection of cases, as well as under-reporting of detected cases. However, the experience thus far suggests that the disease is less severe in Africa compared with Europe, North America, Asia and South America. ${ }^{4}$ On 22 May 2020, WHO even stated that the pandemic 'appears to be taking a different pathway in Africa' and that 'so far, Africa has not experienced the high mortality seen in some parts of the world'. ${ }^{5}$ Postulated reasons for this include Africa's younger demographic, higher average temperatures and the existence of higher levels of pre-existing immunity. ${ }^{6}$

The high transmissibility of COVID-19 and the fact that asymptomatic or presymptomatic individuals may be contagious ${ }^{7}$ has meant that standard communicable disease (CD) control measures involving active case detection, contact tracing and selective isolation and quarantine may be insufficient to bring transmission under control, especially when infection rates are comparatively high. As a consequence, many countries have deployed community-wide 'lockdown' measures to reverse exponential epidemic growth trajectories.

Although the term 'lockdown' is now ubiquitous, it is not well-defined. There are also no clear definitions of commonly used adjectives for the term such as 'total lockdown' and 'partial lockdown'; and 'hard' or a 'soft' lockdown. Indeed, WHO's reference to 'so-called lockdown measures' indicates the absence of a clear and universally accepted definition of the term lockdown. ${ }^{8}$ Given its widespread use and importance, we have come up with a definition of 'lockdown' using a two-by-two matrix based on whether measures are compulsory or voluntary; and whether they are targeted at individuals or applied to a general population (table 1).

Using this matrix, we define lockdown as a set of measures aimed at reducing transmission of COVID-19 that are mandatory, applied indiscriminately to a general population and involve some restrictions on the established pattern of social and economic life. This definition has been refined from an earlier published version ${ }^{9}$ and excludes measures that are compulsory but targeted at individuals or applied discriminately to selected premises (eg, the closure of the Wuhan food market which was initially believed to be a point source of infection). It also excludes populationwide measures which are compulsory but do not involve a significant restriction on freedom or the established pattern of social and economic life-for example, being required to wear facemasks (FMs) in public or having to abide by physical distancing (PD) stipulations in public.

The boundaries between the four quadrants of the matrix are blurred and open to some varied interpretation, but based on this system of categorising CD control measures, we have defined 'lockdown' as consisting of three interventions (in bold) located within the bottom right quadrant of the matrix below: (i) geographic containment; (ii) home confinement and (iii) prohibition of gatherings and closure of establishments and premises.

Geographic containment is a type of lockdown measure that is now associated with the decision of Chinese authorities in January 2020 to stop the movement of people in and out of Wuhan city. ${ }^{10}$ It is designed to prevent epidemic hotspots from contaminating other parts of a country or region. Exemptions will usually be made to ensure the flow of food and other essential commodities in and out of a locked down area, and there may be minimal or absent restrictions for people travelling into an area that has been put into lockdown. A cordon sanitaire may accompany geographic containment. This term refers to the creation of a buffer zone around an area experiencing an epidemic across which there is movement control and which therefore acts as a barrier to disease transmission.

Home confinement places requirements on a general population to stay at home for prescribed amounts of time. The term 'curfew' is sometimes used interchangeably

Table 1 Categorisation of communicable disease control measures

\begin{tabular}{|c|c|c|}
\hline & Voluntary/Advisory & Compulsory/Mandatory \\
\hline $\begin{array}{l}\text { Measures targeted at } \\
\text { identifiable individuals } \\
\text { or facilities }\end{array}$ & $\begin{array}{l}\text { Actions and behaviours among identified or } \\
\text { suspected cases, and contacts of cases: } \\
\text { Hygiene measures (including wearing } \\
\text { facemasks) } \\
\text { Physical distancing (ie, measures to reduce } \\
\text { the degree and frequency of physical } \\
\text { proximity with other people, including working } \\
\text { from home) } \\
\text { Isolation or quarantine }\end{array}$ & $\begin{array}{l}\text { Actions and behaviours required of identified or } \\
\text { suspected cases, and contacts of cases: } \\
\text { Hygiene measures (including wearing } \\
\text { facemasks) } \\
\text { Physical distancing (ie, measures to reduce the } \\
\text { degree and frequency of physical proximity with } \\
\text { other people, including working from home) } \\
\text { Isolation or quarantine } \\
\text { Closure of identifiable premises deemed to be a } \\
\text { confirmed or potential source of infection }\end{array}$ \\
\hline $\begin{array}{l}\text { Measures applied } \\
\text { indiscriminately to a } \\
\text { general population or } \\
\text { area }\end{array}$ & $\begin{array}{l}\text { Actions and behaviours in general population(s): } \\
\text { Hygiene measures (as above) } \\
\text { Physical distancing (as above) } \\
\text { - Refrain from non-essential travel } \\
\text { - Avoid gatherings of people }\end{array}$ & $\begin{array}{l}\text { Actions and behaviours in general populations: } \\
\text { Hygiene measures (as above) } \\
\text { Ghysical distancing (as above) } \\
\text { Geographic containment } \\
\text { Home confinement } \\
\text { Prohibition of gatherings and closure of } \\
\text { establishments and premises }\end{array}$ \\
\hline
\end{tabular}


with home confinement, and exemptions are typically made for people whose jobs are considered essential, or for certain permitted activities such as shopping for food or taking exercise.

The third type of lockdown measure is the prohibition of gatherings and the closure of establishments and premises. This includes the closure of shops, businesses, schools, universities, restaurants, cinemas, theatres, churches, mosques and sporting venues; and the prohibition or restriction of gatherings of people. As with other types of lockdown, exemptions are common and may apply to essential businesses and industries or certain types of gatherings (eg, funerals). Alternatively, premises may be kept open for defined groups of people (eg, schools being kept open for the children of essential workers).

A clear and bounded definition of lockdown is important from a research perspective because of the need to monitor its effectiveness and impact on disease control. Furthermore, lockdown poses several threats to health and well-being and may even cause more overall harm than good. At the level of individuals, lockdown can result in psychological and emotional distress; loss of employment and household income and deprive children of the benefits of schooling. ${ }^{11}$ These harms are aggravated by the effects of lockdown at the societal level including economic contraction and recession, disruption of supply systems, aggravation of social tensions and the potential for lockdown to lead to the long-term erosion of human rights and civil liberties.

It is therefore necessary for public health systems to monitor and evaluate the impact of lockdown on epidemic control, and its wider social, economic, health and political impacts. Attention should also be paid to evaluating the existence of measures designed to mitigate the harms of lockdown, such as providing financial and welfare support to vulnerable households and businesses, organising online schooling for children and introducing fiscal measures to keep the economy afloat.

This paper describes the design, timing and implementation of the three types of lockdown in a set of nine countries in SSA: Ghana, Nigeria, South Africa, Sierra Leone, Sudan, Tanzania, Uganda, Zambia and Zimbabwe (see table 2 and figure 1). It also describes the manner in which lockdown was enforced and the efforts to mitigate the harms of lockdown.

The research was conducted by a group of countrybased researchers who volunteered to participate in what was designed to be a rapid research exercise. Data were collected by country-based researchers using a semistructured questionnaire, supplemented with additional data obtained from the WHO and the African Centres for Disease Control and Prevention websites, and other reliable sources on the worldwide web. Due to constraints in space, we provide a summarised description of lockdown and its impacts here. However, the full set of data we collected is available (on request) for other researchers to assess and use for other studies.

\section{OVERVIEW OF LOCKDOWN MEASURES (MARCH TO MID-JUNE 2020)}

Although there were some commonalities across the nine countries, a more notable finding was the variation in the design, timing and implementation of lockdown measures (see table 3 for a tabulated summary). Tanzania lies at one end of the spectrum with minimal use of lockdown measures while South Africa and Uganda were more extensive and strict in their deployment of lockdown measures. In Nigeria's federal system, devolution of authority to state governments resulted in lockdown being applied differently across different states making it hard to provide an overall description for the country.

Table 2 Demographic information of nine sub-Saharan countries

\begin{tabular}{|c|c|c|c|c|c|c|}
\hline & Population size & $\begin{array}{l}\text { Average } \\
\text { life } \\
\text { expectancy }\end{array}$ & $\begin{array}{l}\text { GDP per } \\
\text { capita \$ PPP } \\
(2018)\end{array}$ & $\begin{array}{l}\text { Human } \\
\text { Development Index } \\
(2018)\end{array}$ & GHSI (2019) & $\begin{array}{l}\% \text { population } \\
\text { urban }(2018)\end{array}$ \\
\hline Nigeria & 206139589 & 58.5 & 5991 & 0.534 & 19.9 & 50.3 \\
\hline Sierra Leone & 7976983 & 54.3 & 1602 & 0.438 & 38.2 & 42.1 \\
\hline Tanzania & 59734218 & 65.0 & 3240 & 0.528 & 36.4 & 33.8 \\
\hline Uganda & 45741007 & 63.0 & 2038 & 0.528 & 44.3 & 23.8 \\
\hline Zambia & 18383955 & 63.5 & 4224 & 0.591 & 28.7 & 43.5 \\
\hline Zimbabwe & 14862924 & 51.1 & 3030 & 0.563 & 38.2 & 32.2 \\
\hline
\end{tabular}

World Bank Database (https://data.worldbank.org/), United Nations Development Programme (UNDP) (http://hdr.undp.org/en/data) and the Global Health Security Index (GHSI) (https://www.ghsindex.org/). ${ }^{24-26}$ 


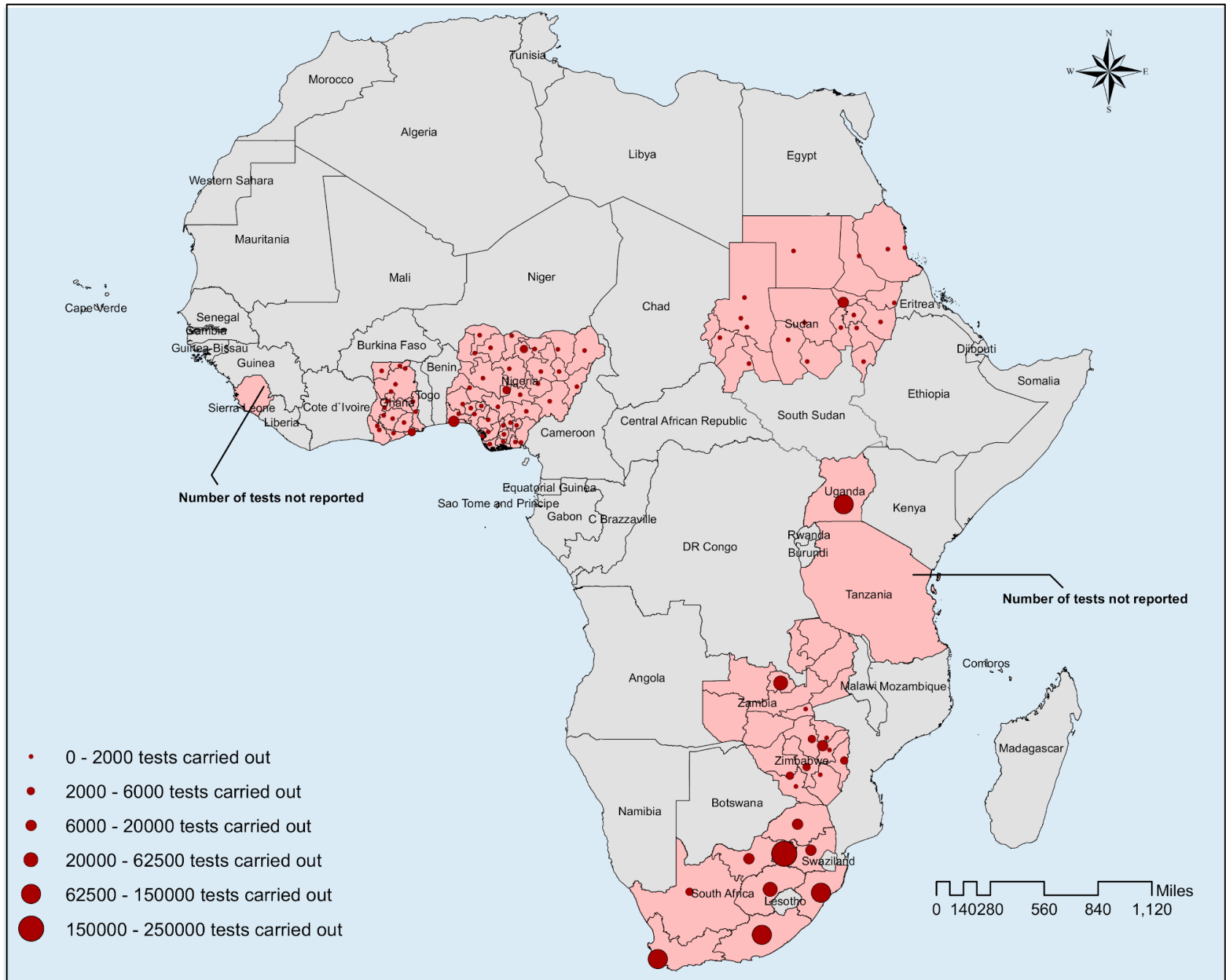

Figure 1 The map with nine countries of sub-Saharan Africa including the number of samples tested in seven countries (location of testing canters and number is shown for Nigeria, Ghana, South Africa, Sudan and Zimbabwe and aggregated national number is shown for Uganda and Zambia) as of 15 May 2020. The data on number of samples tested were collected from researcher (author of this paper) of respective countries. In most of the cases, the source of the number of samples tested were the website of Ministry of Health of the respective country. In some instances, it was through personal communication with the Ministry of Health of respective country.

One of the commonalities across the nine countries was the suspension of international passenger flights relatively early in the epidemic. Land and sea border crossings were also restricted, with exceptions made for the continued passage of goods and commodities. The geographic containment of areas within countries was less common with only Nigeria and Ghana targeting lockdown measures to selected areas within the country. Most countries continued with restrictions on international travel, but in Tanzania, the government began lifting restrictions and removed mandatory quarantine for international arrivals in May (although with enhanced screening of passengers on arrival).

In all of the countries studied, with the exception of Sierra Leone and Tanzania, non-essential businesses, restaurants, cafes and recreational establishments were closed, although with shops and markets being allowed to continue selling food and other essential commodities.
In Sierra Leone, all shops and businesses were allowed to stay open except during two 3-day periods of lockdown; while in Tanzania, there were no closure at all of shops, government offices, parliamentary sessions, religious congregations, restaurants and cafes. All countries, including Sierra Leone and Tanzania, closed down schools, colleges and universities, and prohibited or restricted public and private gatherings to greater or lesser degrees. For example, in Sierra Leone only gatherings of $>100$ were prohibited; while in Ghana and Tanzania gatherings of $>25$ and 10 people, respectively were prohibited.

There is evidence of all countries allowing businesses to reopen from the middle of April. In Ghana, businesses and other workplaces were allowed to reopen with PD and hygiene protocols in place. In Zambia, although restaurants, gyms and casinos were allowed to re-open on 8 May, bars and taverns remained closed. In Zimbabwe, 
Table 3 Summary of lockdown measures in nine sub-Saharan African countries (March-June 2020)

\begin{tabular}{|c|c|}
\hline & Geographic containment \\
\hline Ghana & $\begin{array}{l}21 / 3-\text { National borders closed to } \\
\text { international travellers. } \\
\text { There were travel restrictions in and } \\
\text { out of Accra and Kumasi during the } \\
\text { lockdown, except people travelling } \\
\text { with essentials including food crops. }\end{array}$ \\
\hline Nigeria & $\begin{array}{l}\text { 23/3-suspension of international air } \\
\text { passenger travel is still in force. } \\
30 / 3-\text { geographic containment of } \\
\text { Abuja, Lagos and Delta states. } \\
23 / 4 \text { - interstate travel restrictions } \\
\text { announced across country. } \\
\text { In other states, varying degrees of } \\
\text { geographic containment. }\end{array}$ \\
\hline
\end{tabular}

\section{Closures and prohibitions}

16/3-prohibition of gatherings of $>25$ persons.

Closures: (i) schools, colleges and universities;

(ii) religious buildings; (iii) non-essential shops;

(iv) restaurants, bars and cafes; (v) recreational parks and facilities.

20/4-businesses and other workplaces allowed to reopen with physical distancing and hygiene protocols. Ban on gatherings and closure of schools, colleges and universities remain in place.

25/3 - closure of schools, colleges and universities.

30/3-countrywide prohibition of gatherings/ closures: (i) religious buildings; (ii) non-essential shops; (iii) restaurants, bars and cafes; (iv) recreational parks and facilities.

27/4-relaxation of closures and prohibitions in Lagos, Abuja and Ogun States.

\section{Home confinement}

30/3-home confinement in the Accra and Greater Kumasi metropolitan areas, initially for 2 weeks then extended for an additional week. 20/4-home confinement in Accra and greater Kumasi discontinued.

\begin{tabular}{|c|c|}
\hline Sierra Leone & $\begin{array}{l}21 / 3 \text {-international air passenger } \\
\text { flights suspended. } \\
27 / 3 \text { - closure of land borders } \\
\text { except for cargo. } \\
\text { Interdistrict travel restrictions have } \\
\text { been in place continuously for about } \\
\text { a month. }\end{array}$ \\
\hline South Africa & $\begin{array}{l}15 / 3-\text { ban on international flights. } \\
27 / 3 \text { - restrictions on travel within } \\
\text { country. } \\
1 / 5 \text { to } 7 / 5 \text {-internal travel restrictions } \\
\text { temporarily lifted. }\end{array}$ \\
\hline
\end{tabular}

Sudan $16 / 3$-airports, ports and land
crossings shut down.
30/3-interstate public transportation
halted.

31/3-closure of: i) schools, colleges and universities; ii) churches and mosques/ countrywide prohibition of gatherings of $>100$ people.

Shops, bars, restaurants and cinemas allowed

to open till 21:00 hours daily except during lockdowns. Markets kept open. Parks, beaches, sports clubs, gyms kept open but with physical distancing, mandatory use of facemasks and hand washing.

15/3-prohibition of gatherings of $>100$ people.

18/3-closure: (i) schools, colleges and universities.

27/3 - closures: (i) non-essential shops; (ii) restaurants, bars and cafes; (iii) recreational parks and facilities. Prohibition of all gatherings. $1 / 5$-country moved level 4 . Certain industries reopened and more workers allowed to go to work. More shops opened. Sales of alcohol and cigarettes remain prohibited. Restaurants, bars, cafes and recreational parks and facilities remain provided this is not done in organised closed. Schools, colleges and universities remain groups and within $5 \mathrm{~km}$ of home. closed except for controlled return of final year medical students.

\section{$12 / 3$ - closure: schools}

$14 / 3$ - closure: universities and colleges.

1/4-countrywide prohibition of sports and cultural events.

2/4: closure in three states: (i) non-essential shops; (ii) restaurants, bars and cafes; (iii) recreational parks and facilities and (iv) worship sites

18/4: closure countrywide: (i) non-essential shops; (ii) restaurants, bars and cafes; (iii) recreational parks and facilities 30/3-home confinement in Lagos, Abuja, Delta and Ogun states for 2 weeks, and then extended for another 2 weeks.

16/4 - home confinement in Kano state for 1 week.

21/4 - home confinement in Taraba state.

1/4-delta state announces home confinement and a dawn-to-dusk curfew.

27/4-relaxation of home confinement in Lagos, Abuja and Ogun States. 30/4-relaxation of home confinement in Delta State.

There have been two consecutive stay at home orders lasting 3 days (5-7 April; 3-5 May). A third stay at home for 1 week is expected in end of May. 11/4-countrywide curfew from 21:00 to $06: 00$ hours.

$27 / 3$ - countrywide home confinement with a strict curfew that included a ban on any exercise outside the home. Some essential activities allowed between 08:00 and 17:00 hours. $1 / 5$-under level 4 , everyone is confined to their place of residence from 20:00 to 17:00 hours and persons are allowed to exercise 30/3-countrywide curfew between 18:00 and 06:00 hours. 2/4-home confinement from 13:00 to 07:00 hours in three states (Khartoum, Gezira and Gadaref).

18/4-home confinement extended to whole country for 3 weeks. $9 / 5$ home confinement extended for 5 weeks. 


\begin{tabular}{|c|c|c|c|}
\hline & Geographic containment & Closures and prohibitions & Home confinement \\
\hline Tanzania & $\begin{array}{l}\text { 12/4-international air travel } \\
\text { suspended (but port kept open). } \\
\text { Restrictions have been imposed } \\
\text { against unnecessary movements } \\
\text { between and within affected regions. } \\
\text { Public transport continues from } \\
\text { region to region. } \\
23 / 03-\text { all incoming travellers from } \\
\text { COVID-19 affected countries } \\
\text { required to be in quarantine for } 14 \\
\text { days. } \\
\text { 18/5-international flights ban lifted } \\
\text { and commercial airlines restarted } \\
\text { flights in early June. } \\
27 / 05-\text { all incoming travellers from } \\
\text { COVID-19 affected countries will no } \\
\text { longer be quarantined unless they } \\
\text { have symptoms of COVID-19. }\end{array}$ & $\begin{array}{l}\text { 17/3 - closure: schools (public and private). } \\
\text { 19/3 - closure: colleges and universities (public } \\
\text { and private). } \\
\text { 17/3 - prohibition of gatherings. Marriage and } \\
\text { funeral gatherings restricted to } 10 \text { people. } \\
21 / 4-\text { closure: (i) recreational parks and facilities, } \\
\text { including cinemas and theatres. } \\
\text { Churches and mosques continue to operate } \\
\text { under restriction on observant to COVID-19 } \\
\text { preventive measures. Shops and markets } \\
\text { remain open. Restaurants, bars and cafes kept } \\
\text { open-but bars have to close by } 21: 00 \text { hours in } \\
\text { Dar es Salaam, while some regions like Mwanza } \\
\text { enforced closure by } 22: 00 \text { hours while others did } \\
\text { not introduce any such restrictions. } \\
\text { 1/6-colleges and form six secondary school } \\
\text { students allowed to return to school. }\end{array}$ & $\begin{array}{l}\text { No home confinement except for } \\
\text { students and young children who } \\
\text { were asked to stay at home. } \\
\text { Self-isolation was encouraged for any } \\
\text { person suspected to having interacted } \\
\text { with an infected person. }\end{array}$ \\
\hline Uganda & $\begin{array}{l}\text { 21/3-airports closed (except for } \\
\text { cargo). }\end{array}$ & $\begin{array}{l}\text { 20/3 - closures: (i) schools, colleges and } \\
\text { universities; (ii) non-essential shops; (iii) } \\
\text { restaurants, bars and cafes; (iv) recreational } \\
\text { parks and facilities; (v) religious buildings and } \\
\text { facilities. } \\
20 / 3 \text { - prohibition of gatherings of } 10 \text { or fewer } \\
\text { people initially allowed, and then reduced to } 5 .\end{array}$ & $\begin{array}{l}30 / 3 \text { - countrywide home confinement } \\
\text { announced, and has continued till } \\
\text { mid-June. Curfew from 19:00 to 06:30 } \\
\text { hours. } \\
\text { Private transport has been permitted } \\
\text { since } 25 / 5 \text { for not more than } 3 \text { people } \\
\text { (including the driver) per vehicle. }\end{array}$ \\
\hline Zambia & $\begin{array}{l}\text { 26/3-one international airport kept } \\
\text { open (but three shut). } \\
29 / 4 \text { - all tourist visas suspended. } \\
11 / 5 \text { - land border with Tanzania } \\
\text { closed. } \\
18 / 5 \text { - land border crossing with } \\
\text { Tanzania opened. }\end{array}$ & $\begin{array}{l}26 / 3 \text { - closures: (i) non-essential shops; (ii) } \\
\text { recreational parks and facilities; (iii) restaurants, } \\
\text { bars and cafes (except for take-aways); } \\
\text { gatherings only allowed if fewer than } 50 \text { people. } \\
1 / 4 \text { - closures: (i) schools, colleges and } \\
\text { universities. } \\
8 / 5-\text { restaurants, gyms and casinos are allowed } \\
\text { to re-open, but bars and taverns remain closed. }\end{array}$ & $\begin{array}{l}\text { No home confinement or curfew } \\
\text { implemented. }\end{array}$ \\
\hline Zimbabwe & $\begin{array}{l}\text { 23/3-borders closed. } \\
30 / 3 \text { - in-country travel restrictions. }\end{array}$ & $\begin{array}{l}\text { 23/3-gatherings of }>100 \text { people prohibited. } \\
30 / 3 \text { to 03/05-all public gatherings prohibited } \\
\text { (except for funerals with fewer than } 50 \text { people). } \\
\text { 30/3 - closure: (i) schools, colleges and } \\
\text { universities; (ii) non-essential shops; (iii) } \\
\text { recreational parks and facilities; (iv) restaurants, } \\
\text { bars and cafes (except for takeaways). } \\
\text { 4/5-formal sector businesses can open from } \\
\text { 08:00 to 15:00 hours but not informal sector. }\end{array}$ & $\begin{array}{l}\text { 30/3-home confinement begins. } \\
\text { 2/5-home confinement extended. }\end{array}$ \\
\hline
\end{tabular}

formal sector businesses were allowed to open from 08:00 to 15:00 hours, but not informal traders and markets. Generally speaking, the prohibition of large gatherings and closure of educational facilities continued to remain in place throughout the month of May and into early June.

When it came to home confinement, South Africa and Uganda implemented the strictest measures. In South Africa, a countrywide curfew began at the end of March 2020 and included the prohibition of any exercise outside the home (only essential activities were allowed between 08:00 and 15:00 hours). Restrictions were loosened slightly in early May with strict home confinement only required between 20:00 and 05:00 hours and persons being allowed to exercise between 06:00 and 09:00 hours provided this is done within $5 \mathrm{~km}$ of home and not in groups. In Uganda, home confinement was imposed from March 30 and was still in place as per June 15, with a strict curfew imposed from 19:00 to 06:30 hours.

In Nigeria, a stay at home order in Lagos State, the Federal Capital Territory (Abuja) and Ogun State for about a month was issued by the Federal government, alongside a nationwide curfew from 20:00 to 06:00 hours. In Ghana, home confinement was limited to the two major metropolitan areas of Accra and Kumasi for a 3-week period. Sudan's countrywide curfew initially occurred between 18:00 and 06:00 with extended curfew hours from 13:00 to 07:00 for the states of Khartoum, Gezira and Gadaref. These extended hours were then applied to the whole country in mid-April. In Sierra Leone, a nationwide curfew was implemented from 21:00 to 06:00, supplemented by two 3-day periods (5-7 April; 3-5 May) of 24 hours home confinement. In contrast, 

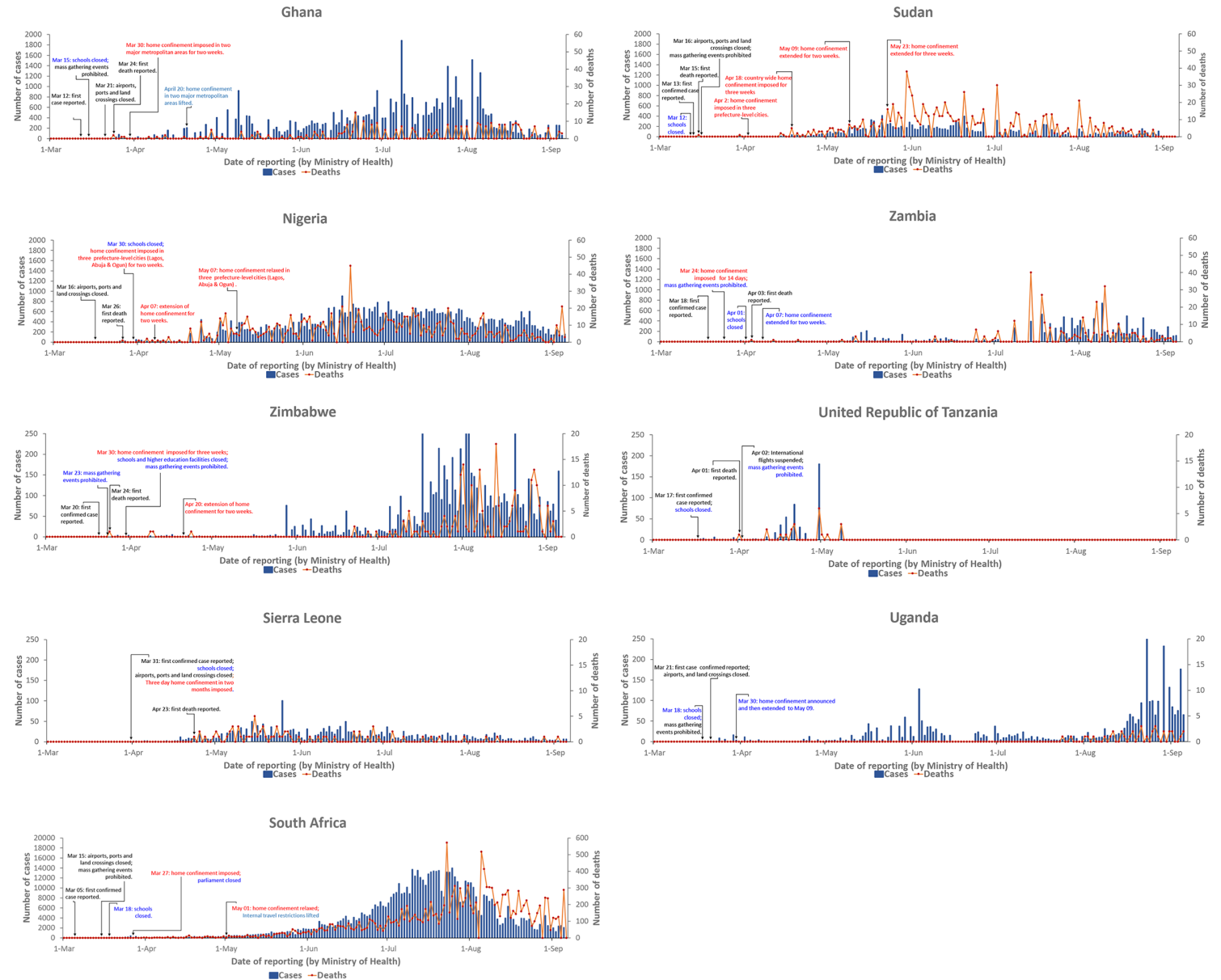

Figure 2 Different measures of lockdown taken in nine sub-Saharan African countries up until 6 September 2020. The daily reported COVID-19 cases are presented in left-hand y-axis and death cases are at right-hand y-axis. Please notice that axis has different values. Nigeria reported its first COVID-19 case on 27 February is not shown in the graph.

home confinement was not implemented in Zambia and Tanzania.

Other CD control measures have been implemented in all nine countries. For example, health information campaigns about COVID-19, hygiene measures such as frequent hand washing, use of FMs and ensuring greater PD have been implemented in all countries. Thus in Tanzania, although all shops have remained open, preventive measures such as hand washing with soap, maintaining PD and wearing of FMs have been widely observed.

Standard CD control measures such as active case detection and isolation, coupled with contact tracing and quarantine have been activated, strengthened and carried out to varying degrees of effectiveness in all countries. This included Ghana, Nigeria, Tanzania, Uganda and Zambia screening and quarantining people who had flown into the country prior to the ban on international travel. Diagnostic testing capacity has been expanded. For example, Ghana started with two diagnostic centres based in major research facilities, but later expanded its capacity to about 10 diagnostic centres. The use of FMs in public has been compulsory for the whole population in Ghana, Sierra Leone, Uganda, Zambia and Zimbabwe; but only in certain parts of the country in Tanzania and Zimbabwe. In South Africa, FMs are compulsory on public transport. A particular feature of Ghana's response has been the use of public disinfection campaigns involving vector-control and waste management companies.

\section{MITIGATION MEASURES}

The degree of harm that may be caused by lockdown will be influenced by the breadth, depth and length of the different lockdown measures. Other factors that will shape the experience of lockdown include the structure of the economy, pre-existing levels of poverty and financial insecurity, the capacity of pre-existing social welfare services, levels of fear about the virus, public trust in government, the degree of social solidarity in society (which influences how people experience lockdown measures psychologically and emotionally) and the deployment of specific mitigation measures.

Most countries implemented some measures to support poor households and small, micro and medium enterprises. In Ghana, a GH\&1.2 billion (about US\$200 million) Coronavirus Alleviation Programme established by the government to support affected households 
and businesses, was complemented by donations from private sector companies and Civil Society Organisations. In South Africa, a social relief and economic support package of R500 billion (about US $\$ 3$ billion) was established to provide additional welfare and emergency water, sanitation and shelter services, among other things. In Uganda, the government distributed food to vulnerable households (but only in Kampala and neighbouring towns in the central region). Government support for poorer households was more limited or absent in Sierra Leone, Tanzania and Zambia, where lockdown measures were less extensive. In Zimbabwe, cash transfers were used to support vulnerable groups. ${ }^{12}$

Indirect forms of support to vulnerable households during lockdown were also provided. For example, in South Africa, landlords were prohibited from evicting any person from their place of residence (whether formal or informal). In Tanzania, water and electricity agencies were ordered not to make any disconnections; while in Ghana, the government gave all citizens 3 months free water; and electricity was provided free for low-income consumers and at half cost for all other consumers in April, May and June 2020. In Nigeria, the Power Holding Company of Nigeria increased the number of hours of electricity available per day to consumers and the price of fuel/petrol was reduced.

Some countries have also implemented interventions to support the economy. South Africa's larger economy and greater fiscal flexibility allowed it implement a social relief and economic support package that was worth about $10 \%$ of its gross domestic product. In Ghana, the International Monetary Fund (IMF) and private banking sector have intervened to keep credit flowing. In Uganda, the Central bank offered support to commercial banks to continue operating, while a loan of US $\$ 491.5$ million from the IMF's Rapid Credit Facility was approved to support the economy.

\section{IMPACT OF LOCKDOWN MEASURES}

The relationship between the mix of lockdown measures and the number of reported COVID-19 cases and deaths for each of the nine countries is shown in figure 2. The graphs show no obvious pattern. The number of reported cases is heavily dependent on the number of tests done, and the available data show a considerable variation in testing rates ranging from 2031 tests per million population in Nigeria to 63928 tests per million population in South Africa (table 4, figure 1).

Drawing conclusions about the impact of lockdown measures on COVID-19 transmission is difficult for several reasons. First, the true pattern of the epidemic cannot be readily deduced from the number and pattern of reported cases because many infections are undetected and some may be unreported. Second, it is difficult to accurately assess the extent to which the lockdown measures have been properly implemented and adhered to in different parts of the countries, and over
Table 4 Reported cases, tests and deaths (as of 7 September 2020) ${ }^{1}$

\begin{tabular}{lllc}
\hline & $\begin{array}{l}\text { Total } \\
\text { reported } \\
\text { COVID-19 } \\
\text { cases per } \\
\text { million } \\
\text { population }\end{array}$ & $\begin{array}{l}\text { Total } \\
\text { reported } \\
\text { COVID-19 } \\
\text { tests per } \\
\text { million } \\
\text { population }\end{array}$ & $\begin{array}{l}\text { Total } \\
\text { reported } \\
\text { COVID-19 } \\
\text { deaths } \\
\text { per million } \\
\text { population }\end{array}$ \\
\hline Ghana & 1439 & 14328 & 9 \\
\hline Nigeria & 266 & 2031 & 5 \\
Sierra Leone & 257 & NA & 9 \\
\hline South Africa & 10741 & 63928 & 250 \\
Sudan & 305 & NA & 19 \\
\hline Tanzania & 9 & NA & 0.4 \\
Uganda & 82 & 8951 & 1 \\
\hline Zambia & 692 & 6677 & 16 \\
\hline Zimbabwe & 478 & 10217 & 14 \\
\hline
\end{tabular}

Source: Worldometers. ${ }^{1}$

NA, not available.

time. Finally, it is not possible to disentangle the effects of different lockdown measures from each other, as well as from other $\mathrm{CD}$ control measures.

Nonetheless, logic and evidence from elsewhere indicates that lockdown measures will have lowered the effective reproduction rate of the virus in these nine countries. In particular, geographic containment, travel restrictions $^{13}$ and the prohibition of large gatherings would have inhibited community transmission. The relatively large percentage of people living in rural areas where there is naturally more PD and less population mixing may also have contributed to preventing a large national epidemic spike.

However, it is plausible that lockdown measures could have helped increase COVID-19 transmission in the large and dense informal or semi-formal settlements of Africa. In Accra, for example, about $53 \%$ of households live in a single room, ${ }^{14}$ while an even larger proportion relies on public toilets, where PD and home confinement cannot be practically observed. There are also reports from Zimbabwe that overcrowded and poorly managed quarantine centres have acted as hotspots of transmission.

Although COVID-19 can cause severe illness in the SSA context, the number of reported COVID-19 deaths per million population is not as high in Europe and North America. ${ }^{1}$ Meanwhile, concern about the 'collateral damage' of lockdown measures is increasing. The World Bank predicted in April 2020 that the economy across the continent could contract by up as much as $5.1 \%$ due to a decline in output growth among the region's key trading partners, a fall in commodity prices, reduced tourism activity as well as lower levels of foreign direct investment and remittances. ${ }^{1315}$ Countries dependent on oil exports and mining are expected to be hit hardest. ${ }^{16}$ The collapse of the international tourist industry will be felt hardest in 
Sudan, Uganda and Tanzania, where tourism makes up a high proportion of overall national income.

Of the nine countries studied here, South Africa stands apart with its relatively large economy (see table 4), allowing the government greater fiscal space with which to support vulnerable households and the economy. Most of the other countries are much more vulnerable to the negative economic effects of lockdown, and the role of the IMF in enabling countries to access credit and default on debt payments will be crucial in the coming months. Poor households will be hit hardest, especially in urban and peri-urban areas where many are dependent on daily wage labour in the informal economy and where it is not possible to live off a subsistence economy. Furthermore, the number of poor households will grow as the formal economy contracts and unemployment levels rise. Although rural areas have been less affected by both the virus and lockdown measures, rural households will be affected by a reduction in remittances from family members working in urban areas.

Although the agriculture and food sectors have continued to operate, the World Bank has estimated that the agriculture sector could contract by up to $7 \%$; and that food imports could decline substantially from $13 \%$ to $25 \%$ due to a combination of higher transaction costs and reduced domestic demand. ${ }^{16}$ As currencies weaken and the price of food items rise, more households will experience hunger and food insecurity.

The impact of rising household poverty and food insecurity will be aggravated further by the psychological and emotional distress accompanying home confinement. Reports of an increase in the incidence of domestic and intimate partner violence points to lockdown measures having a gender dimension. ${ }^{17}$ This includes the disproportionate impact of the closure of schools and other educational establishments on girls and women, which will also increase social and health inequalities as children from poorer homes suffer disproportionately from educational deprivation. In some places, the closure of schools will add to economic and food insecurity among the poorest households due to the absence of school meals.

Health may also be harmed as a result of conflict and violence arising from agencies such as the police and army compelling and sanctioning households and communities that are unable or unwilling to comply with the measures. In South Africa, both the Human Rights Commission and the Independent Police Investigative Directorate made pointed statements about monitoring and investigating incidents of police misconduct and human rights abuses during the lockdown, ${ }^{18} 19$ while in Ghana, the police promised 'democratic policing strategies'. ${ }^{20}$

Lockdown has also affected the functioning of the health system by increasing physical and financial barriers to accessing healthcare, diverting attention and resources towards COVID-19, and causing patients to stay away from hospitals for fear of contracting COVID-19. A recent study that modelled the impact of COVID-19 on the interruption of HIV/AIDS, tuberculosis (TB) and malaria services in low-income and middle-income countries predicted a $10 \%-36 \%$ increase in related deaths over a 5 -year period. ${ }^{21}$ It was predicted that the greatest impact from HIV would be from interruptions of antiretroviral therapy; reductions in the timely diagnosis and treatment of new TB cases and disruptions to insecticidetreated bednet campaigns for malaria. Another concern is the interruption of vaccine delivery due to overstretched healthcare services, parents not bringing their children to clinics because of COVID-19 and disruptions to vaccine supply chains. ${ }^{22}$

Lockdown measures can also have negative political consequences that public health agencies should consider. These include the prolonging or disproportionate imposition of restrictions on personal freedoms and civil liberties, as well as the suspension of democratic procedures and safeguards. Several countries have declared states of emergency in response to COVID-19, giving governments extraordinary powers. Such powers should be proportionate to the magnitude and nature of the threat faced by a country, and should ideally be kept under constant review. In Ghana, there was considerable debate over whether some lockdown measures should have been lifted in the third week of April.

Many of the collateral effects of the lockdown are negative. However, there are also positive effects. These include a reduction in greenhouse gas emissions and other pollutants, ${ }^{23}$ a lowering in the incidence of traffic accidents and the creation of more time for some families to be together. In South Africa, the banning of alcohol and tobacco sales has also had positive health impacts. COVID-19 and lockdown also offer a stimulus for governments to reappraise globalised economic, trade and transport systems, animal-based food systems and ecosystems and biodiversity issues with the aim of improving resilience and reducing risk in relation to the emergence of new infectious disease risks. The interdependence of communities and states, as revealed by COVID-19, also provides an opportunity to reassert social and cultural institutions that encourage trust, respect and tolerance instead of creating fear and suspicion.

\section{CONCLUSIONS}

The use of lockdown measures to control COVID-19 is undeniably complex. Not only do the measures have wideranging health, social, political and economic effects that produce both benefits and harms, the benefits and harms of lockdown measures are not shared equally across a country's population. Furthermore, the full impact of lockdown measures will only be known many years into the future. The associated collateral effects of worsening poverty and food insecurity, as well as uncertainty about the feasibility of effective COVID-19 control transmission, raises particular questions about the appropriateness of lockdown in the SSA context. This paper highlights the 
need for intersectoral and transdisciplinary research that is capable of providing a rigorous and holistic assessment of the harms and benefits of lockdown. However, it may be reasonable at this moment in time to suggest that the threats of COVID-19 and the collateral damage of lockdown measures are respectively lower and greater in SSA than in other regions of the world.

\section{Author affiliations}

${ }^{1}$ Pathobiology and Population Science, The Royal Veterinary College, London, UK ${ }^{2}$ Department of Communication Studies, University of Ghana, Legon, Ghana ${ }^{3}$ College of Medicine, Ambrose Alli University, Ekpoma, Nigeria and Institute of Lassa Fever Research and Control, Irrua Specialist Teaching Hospital, Irrua, Nigeria ${ }^{4}$ Community Medicine, Irrua Specialist Teaching Hospital, Irrua, Edo, Nigeria ${ }^{5}$ Mercy Hospital Research Laboratory, Freetown, Sierra Leone ${ }^{6}$ Department of Pubic Health, University of KwaZulu-Natal, Durban, South Africa ${ }^{7}$ Department of Infectious Disease Epidemiology, London School of Hygiene \& Tropical Medicine, London, UK

${ }^{8}$ Department of Parasitology and Medical Entomology, Institute of Endemic Diseases, University of Khartoum, Khartoum, Sudan

${ }^{9}$ Noguchi Memorial Institute for Medical Research, University of Ghana, Legon, Ghana

${ }^{10}$ SACIDS Foundation for One Health, Sokoine University of Agricultue, Morogoro, Tanzania

${ }^{11}$ Department of Policy Analysis and Advocacy, National Institute for Medical Research, Dar es Salaam, Tanzania

${ }^{12}$ Department of Paediatrics, Kilimanjaro Christian Medical University College, Moshi, Tanzania

${ }^{13}$ Kilimanjaro Clinical Research Institute, Moshi, Tanzania

${ }^{14}$ National Institute for Medical Research Mwanza Research Centre, Mwanza, Tanzania

${ }^{15}$ School of Public Health, Makerere University College of Health Sciences, Kampala, Uganda

${ }^{16}$ Ministry of Health, Lusaka, Zambia

${ }^{17}$ Biomedical Research and Training Institute, Harare, Zimbabwe

${ }^{18}$ Department of Clinical Research, London School of Hygiene and Tropical Medicine, London, UK

${ }^{19}$ Austrian Sickness Fund, Vienna, Austria

${ }^{20} \mathrm{Health}$ Economics and Health Policy, Institute for Advanced Studies, Vienna, Austria

${ }^{21}$ Health Policy, London School of Economics and Political Science, London, UK

${ }^{22}$ Centre for Clinical Microbiology, University College London, London, UK

${ }^{23}$ Institute of Population Health Sciences, Barts and London Medical and Dental

School, Queen Mary University of London, London, UK

Twitter Najmul Haider @HaiderNajmul, Rashid Ansumana @ansumanaR, Dorothy Yeboah-Manu @DorothyYeboahM1 and David Musoke @DavidMusoke14

Contributors DM and RK conceptualised the study. DM, NH and AY coordinated data collection and analysis. DM and NH prepared the first draft manuscript. All coauthors reviewed the manuscript, provided critical comments and gave their concurrence before its submission to the journal for publication.

Funding NH, AYO, AG, DA, RA, MMAH, DY-M, LM, NK, PCK, AZ and RK are part of PANDORA-ID-NET Consortium (EDCTP Reg/Grant RIA2016E-1609) funded by the European and Developing Countries Clinical Trials Partnership (EDCTP2) programme, which is supported under Horizon 2020, the European Union's Framework Programme for Research and Innovation.

Competing interests None declared.

Patient consent for publication Not required.

Provenance and peer review Not commissioned; externally peer reviewed.

Data availability statement All data relevant to the study are included in the article.

Open access This is an open access article distributed in accordance with the Creative Commons Attribution Non Commercial (CC BY-NC 4.0) license, which permits others to distribute, remix, adapt, build upon this work non-commercially, and license their derivative works on different terms, provided the original work is properly cited, appropriate credit is given, any changes made indicated, and the use is non-commercial. See: http://creativecommons.org/licenses/by-nc/4.0/.

\section{ORCID iDs}

Najmul Haider http://orcid.org/0000-0002-5980-3460

Muzamil Mahdi Abdel Hamid http://orcid.org/0000-0002-6157-4388

Leonard Mboera http://orcid.org/0000-0001-5746-3776

David Musoke http://orcid.org/0000-0003-3262-3918

\section{REFERENCES}

1 Worldometer. Reported cases and deaths by country, Territory, or conveyance: COVID-19 pandemic. Worldometer, 2020. Available: https://www.worldometers.info/coronavirus/\#countries [Accessed Aug 2020]

2 Haider N, Yavlinsky A, Simons D, et al. Passengers' destinations from China: low risk of novel coronavirus (2019-nCoV) transmission into Africa and South America. Epidemiol Infect 2020;148:e41.

3 Miyachi T, Tanimoto T, Kami M. Evaluation of modelling study shows limits of COVID-19 importing risk simulations in sub-Saharan Africa. Epidemiol Infect 2020;148:e113.

4 Mougeni F, Mangaboula A, Lell B. The potential effect of the African population age structure on COVID-19 mortality. Medrxiv 2020.

5 WHO Africa. Africa COVID-19 cases top 100000. Brazzaville, 2020.

6 Njenga MK, Dawa J, Nanyingi M, et al. Why is there low morbidity and mortality of COVID-19 in Africa? Am J Trop Med Hyg 2020;103:564-9.

7 Lavezzo E, Franchin E, Ciavarella C, et al. Suppression of COVID-19 outbreak in the municipality of Vo, Italy. medRxiv 2020.

8 WHO. WHO Director-General's opening remarks at the media briefing on COVID-19. Geneva, Switzerland, 2020.

9 Mboera LEG, Akipede GO, Banerjee A, et al. Mitigating lockdown challenges in response to COVID-19 in sub-Saharan Africa. Int $J$ Infect Dis 2020;96:308-10.

10 Lau H, Khosrawipour V, Kocbach P, et al. The positive impact of lockdown in Wuhan on containing the COVID-19 outbreak in China. $J$ Travel Med 2020;27. doi:10.1093/jtm/taaa037. [Epub ahead of print: 18 May 2020].

11 Brooks SK, Webster RK, Smith LE, et al. The psychological impact of quarantine and how to reduce it: rapid review of the evidence. Lancet 2020;395:912-20.

12 Mugabe T. Covid-19 relief cash transfers start today as virus cases rise to 18. Her, 2020.

13 Lau H, Khosrawipour V, Kocbach P, et al. The association between international and domestic air traffic and the coronavirus (COVID-19) outbreak. J Microbiol Immunol Infect 2020;53:467-72.

14 Addo IA. Assessing residential satisfaction among low income households in multi-habited dwellings in selected low income communities in Accra. Urban Stud 2016;53:631-50.

15 The World Bank. COVID-19 (coronavirus) drives sub-Saharan Africa toward first recession in 25 years, 2929.

16 Zeufack AG, Calderon C, Kambou G. Africa's pulse, No. 21, Spring 2020 : an analysis of issues shaping Africa's economic future. Washington, DC: World Bank, 2020.

17 UN News. UN chief calls for domestic violence 'ceasefire' amid 'horrifying global surge', 2020.

18 South African Human Rights Commission. SAHRC continues to monitor human rights observance and calls for calm. Braamfontein, 2020.

19 Centre for Human Rights (University of Pretoria). Centre for human rights expresses Grave concern about high level and racialised nature of excessive force during lockdown, 2020.

20 MyJoyOnline. We'll use 'democratic policing strategies' to enforce partial lockdown - Police; 2020.

21 Hogan AB, Jewell ES-S, Vesga J, et al. Report 19: the potential impact of the COVID-19 epidemic on HIV, TB and malaria in lowand middle-income countries. Imp Coll Lonodon.

22 Nelson R. COVID-19 disrupts vaccine delivery. Lancet Infect Dis 2020;20:546.

23 Le Quéré C, Jackson RB, Jones MW, et al. Temporary reduction in daily global CO2 emissions during the COVID-19 forced confinement. Nat Clim Chang 2020;10:647-53.

24 The World Bank. World bank open data: free and open access to global development data, 2020.

25 UNDP. 2019 human development index ranking, 2019.

$26 \mathrm{NTI}$ and Johns Hopkins University Centre for Health Security. Global health security index, 2019. 